\title{
Analisis Penerapan Metode Job Order Costing dalam Perhitungan Harga Pokok Produksi CV. Berdikari Jaya
}

* Kurnia Hairunnisa

Fakultas Ekonomi dan Bisnis, Universitas Bhayangkara, Indonesia

DOI: $10.46821 /$ equity.v1i2.175

\begin{abstract}
ABSTRAK
Metode job order costing merupakan metode perhitungan harga pokok produksi yang bertujuan untuk mengetahui harga pokok pesanan dengan tepat. Tujuan dari penelitian ini adalah untuk mengetahui bagaimana perhitungan harga pokok produksi yang sesuai dengan metode Job Order Costing. Dari hasil penelitian, dapat disimpulkan bahwa CV Berdikari Jaya menggunakan perhitungan harga pokok produksi dengan metode Job Order Costing namun ada kesalahan dalam pencatatan biaya bahan baku dan biaya overhead pabrik. Hasil perhitungan menunjukkan perbedaan yang signifikan antara perhitungan harga pokok produksi CV Berdikari Jaya dengan perhitungan berdasarkan job order costing. Perbedaan tersebut akan berpengaruh terhadap harga jual dan laba rugi perusahaan.
\end{abstract}

Kata Kunci: Job Order Costing, Harga Pokok Produksi, Biaya Overhead Pabrik

\begin{abstract}
Job order costing method is a method of calculating the cost of production that aims to find out the order price right. The purpose of this study is to find out how to calculate the cost of production in accordance with the Job Order Costing method. From the results of the study, it can be concluded that CV Berdikari Jaya using the calculation of the cost of production by Job Order Costing method but there are errors in recording material costs and factory overhead costs. The calculation results show a significant difference between the calculation of the cost of production of $C V$ Berdikari Jaya with the calculation based on job order costing. This difference will affect the selling price and profit and loss of the company.
\end{abstract}

Keywords: Job Order Costing, Cost of Goods Sold, Factory Overhead Cost.

\section{PENDAHULUAN}

Salah satu tujuan perusahaan adalah menghasilkan laba semaksimal mungkin dengan biaya seminimal mungkin. Untuk itu dibutuhkan cara dalam pengendalian biaya salah satunya adalah pencatatan dan pembebanan biaya yang tepat terhadap setiap proses produksinya. Salah satu metode pencatatan biaya produksi yaitu metode job order costing. Tujuan dari pencatatan dengan metode job order costing adalah untuk mengetahui harga pokok produksi pada setiap pesanan dengan tepat.

Perusahaan CV Berdikari Jaya adalah sebuah perusahaan yang bergerak di bidang industri karoseri yaitu perusahaan pembuatan dump truck dengan berbagai jenis dan bentuk. Dalam operasinya, CV Berdikari Jaya memproduksi dump truck 
dengan spesifikasi dan nilai yang berbeda satu sama lainnya tergantung pada permintaan konsumen. Dalam praktiknya, CV Berdikari Jaya telah mengaplikasikan metode job order costing, hal ini dapat dilihat dari pemisahan biaya bahan baku dan biaya tenaga kerja langsung per pesanan. Namun perusahaan kesulitan dalam pembebanan Biaya Overhead Pabrik terhadap setiap pesanan. Pembebanan biaya overhead pabrik oleh perusahaan dilakukan dengan membebankan biaya overhead pabrik sesungguhnya dengan menambahkan taksiran biaya lain-lain sebesar Rp 2.000 .000 per pesanan sebagai taksiran biaya overhead pabrik nonkas.

Tujuan dari penelitian ini adalah untuk mengetahui bagaimana perhitungan harga pokok produksi yang sesuai metode Job Order Costing pada CV Berdikari Jaya. Perhitungan harga pokok produksi yang tepat dapat digunakan perusahaan untuk menentukan harga jual dan laba diinginkan. Selain itu perusahaan dapat memutuskan pesanan mana yang akan diambil atau tidak.

\section{METODE PENELITIAN}

Pendekatan penelitian yang digunakan adalah pendekatan penelitian kualitatif yang menitikberatkan pada logika berpikir, memilih antara rumusan masalah, tujuan, teknik, dan paradigma atau konsep berpikir untuk mengetahui makna dari suatu fenomena.

Teknik pengumpulan data adalah cara atau metode yang dipakai oleh peneliti untuk mengumpulkan data. Dalam penelitian ini metode yang digunakan adalah sebagai berikut:

a. Library research

b. Penelitian Lapangan (field research)

Penelitian lapangan yang dilakukan secara langsung terhadap objek yang diteliti dengan menggunakan beberapa teknik :

a. Wawancara (interview)

b. Pengamatan (observasi)

c. Dokumentasi

Data hasil penelitian diolah dan dianalisis secara deskriptif dengan pendekatan kualitatif sebagai berikut :

a. Identifikasi data dan dokumen yang berkaitan dengan perhitungan harga pokok produksi pada CV Bedikari Jaya

b. Mengevaluasi perhitungan harga pokok produksi pada CV Berdikari Jaya

c. Memberikan usulan/rekomendasi perhitungan harga pokok produksi menurut metode Job Order Costing sebagai solusi dari kesalahan perhitungan harga pokok produksi pada CV Berdikari Jaya

d. Kesimpulan dan Saran

\section{HASIL DAN PEMBAHASAN}

Setiap pesanan yang dikerjakan mempunyai karakteristik dan tingkat kesulitan yang berbeda antara satu dengan yang lain. Hal ini menyebabkan perbedaan komponen biaya produksi untuk masing-masing jenis pesanan. Untuk menunjukkan perhitungan biaya produksi produk untuk tiap-tiap pesanan pada CV Berdikari Jaya, dalam penelitian ini penulis mengambil contoh penghitungan biaya produksi produk jenis sparepart pesanan Dump Dropside Light Truck. Alasan penulis menggunakan contoh tersebut karena merupakan pesanan jenis produk karoseri dengan kuantitas terbanyak pada tahun 2017. 


\section{Perhitungan Harga Pokok Produksi Menurut Perusahaan}

\section{Biaya Bahan Baku}

CV Berdikari Jaya mengklasifikasikan bahan baku yang dibutuhkan dalam proses produksinya menjadi 3 yaitu bahan baku utama, baan baku pendukung dan bahan baku warna. Adapun penghitungan biaya bahan baku untuk pesanan tersebut dapat dilihat pada tabel 1 .

\section{Perhitungan Biaya Tenaga Kerja Langsung}

CV Berdikari Jaya menghitung biaya tenaga kerja langsung berdasarkanbiaya sesungguhnya yang dikeluarkan, yaitu tenaga kerja yang terlibat langsung dengan proses produksi yang meliputi tenaga kerja kontruksi, tenaga kerja instrumen dan tenaga kerja pengecatan dengan tarif yang sudah ditentukan diawal saat Surat Perintah Kerja turun ke lapangan.

Adapun jumlah biaya tenaga kerja langsung untuk masing-masingpesanan dapat disajikan pada tabel 2.

\section{Perhitungan Biaya Overhead Pabrik}

CV Berdikari Jayamelakukan pembebanan Biaya Overhead Pabrik dengan mengidentifikasi Biaya Overhead Pabrik Sesungguhnya yang melekat pada pesanan. Adapun jumlah penghitungan biaya overhead pabrik sesungguhnya dapat dilihat pada tabel 3 .

Tabel 1

Perhitungan Biaya Bahan Baku 1 unit Dump Dropside Light Truck

\begin{tabular}{llllll}
\hline No & Nama Bahan & Qty & Satuan & Harga/Qty & Jumlah \\
\hline 1 & Plat 1,4X4'X8 & 2 & Lbr & $280.000,00$ & $560.000,00$ \\
2 & Plat 2,8X4'X8' & 6 & Lbr & $560.000,00$ & $3.360 .000,00$ \\
3 & Plat 3,5 X4'X8 & 1 & Lbr & 712.000 .00 & $712.000,00$ \\
4 & Plat 3,8X4'X8 & 3 & Lbr & $863.000,00$ & $2.589 .000,00$ \\
5 & Plat Strip 6 x 3/4 x 6 & 3 & Lbr & $115.000,00$ & $345.000,00$ \\
6 & Plat Afalan 6mm & 3 & Lbr & $150.000,00$ & $450.000,00$ \\
7 & UNP/Kanal 100X6 & 8 & Ljr & $290.000,00$ & $2.320 .000,00$ \\
& mtr & & & & \\
8 & UNP/Kanal 120X6 & 4 & Ljr & $433.000,00$ & $1.732 .000,00$ \\
& mtr & Ljr & $180.000,00$ & $360.000,00$ \\
9 & UNP/Kanal 65X6 mtr & 2 & Ljr & $210.000,00$ & $1.785 .000,00$ \\
10 & UNP/Kanal 80X6 mtr & 8.5 & Ljr & $750.000,00$ & $247.500,00$ \\
11 & UNP Kanal 150 x 6 & 0.33 & Bh & $3.700 .000,00$ & $3.700 .000,00$ \\
& mtr & 1 & Roll & $12.000,00$ & $576.000,00$ \\
12 & Hydraulic & 48 & Set & $1.350 .000,00$ & $1.350 .000,00$ \\
13 & Kawat Las & 1 & Set & $1.230 .000,00$ & $1.230 .000,00$ \\
14 & Pompa & 1 & Set & $320.000,00$ & $320.000,00$ \\
15 & Sparepart & 1 & Set & $210.000,00$ & $210.000,00$ \\
16 & Perlengkapan Baut & 1 & & $21.846 .500,00$ \\
17 & Accecories & & & & \\
& TOTAL & & &
\end{tabular}

Sumber: CV Berdikari Jaya (2018) 


\section{Tabel 2}

Biaya Tenaga Kerja Langsung 1 unit Dump Light Truck Dropside

\begin{tabular}{llcc}
\hline No & Jenis tenaga kerja & Gaji per pesanan & Lama pengerjaan \\
\hline 1 & Tenaga Kerja Kontruksi & 4.000 .000 & 5 hari \\
2 & Tenaga Kerja Instrumen & 1.000 .000 & 1 hari \\
3 & Tenaga Kerja Pengecatan & 1.000 .000 & 3 hari \\
& TOTAL & 6.000 .000 & \\
\hline
\end{tabular}

Sumber: CV Berdikari Jaya (2018)

\section{Tabel 3}

Biaya Overhead Pabrik 1 unit Dump Light Truck Dropside

\begin{tabular}{clc}
\hline No & Biaya overhead pabrik & Jumlah \\
\hline 1 & Fee Marketing & 1.000 .000 \\
2 & Biaya Pengiriman Unit & 200.000 \\
3 & Biaya Surat-Surat Kendaraan & 3.500 .000 \\
3 & Biaya Lain-Lain & 2.000 .000 \\
& TOTAL & 6.700 .000 \\
\hline
\end{tabular}

Sumber: CV Berdikari Jaya (2018)

\section{Tabel 4}

Perhitungan Biaya Bahan Baku 1 Unit Dump Light Truck Dropside

\begin{tabular}{llcccr}
\hline No & Nama Bahan & Qty & Satuan & Harga/Qty & \multicolumn{1}{c}{ Jumlah } \\
\hline 1 & Plat 1,4X4'X8 & 2 & Lbr & $280.000,00$ & $560.000,00$ \\
2 & Plat 2,8X4'X8' & 6 & Lbr & $560.000,00$ & $3.360 .000,00$ \\
3 & Plat 3,5 X4'X8 & 1 & Lbr & 712.000 .00 & $712.000,00$ \\
4 & Plat 3,8X4'X8 & 3 & Lbr & $863.000,00$ & $2.589 .000,00$ \\
5 & Plat Strip 6 x 3/4 x 6 & 3 & Lbr & $115.000,00$ & $345.000,00$ \\
6 & Plat Afalan 6mm & 3 & Lbr & $150.000,00$ & $450.000,00$ \\
7 & UNP/Kanal 100X6 mtr & 8 & Ljr & $290.000,00$ & $2.320 .000,00$ \\
8 & UNP/Kanal 120X6 mtr & 4 & Ljr & $433.000,00$ & $1.732 .000,00$ \\
9 & UNP/Kanal 65X6 mtr & 2 & Ljr & $180.000,00$ & $360.000,00$ \\
10 & UNP/Kanal 80X6 mtr & 8.5 & Ljr & $210.000,00$ & $1.785 .000,00$ \\
11 & UNP/Kanal 150X6 mtr & 0.33 & Ljr & $750.000,00$ & $247.500,00$ \\
& TOTAL & & & & $14.460 .500,00$ \\
\hline
\end{tabular}

Sumber: Data Diolah, 2018

\section{Perhitungan Biaya Tenaga Kerja Langsung}

Perhitungan Biaya Tenaga Kerja langsung yang dibebankan oleh CV Berdikari Jaya pada setiap pesanan sudah tepat. Perusahaan menerapkan sistem upah borongan dalam pengerjaan setiap pesanan. Hal ini sesuai dengan teori pada akuntansi bahwa biaya tenaga kerja langsung adalah biaya tenaga kerja yang melekat pada setiap produk. Telah diketahui bahwa biaya tenaga kerja langsung untuk 1 unit dump dropside adalah $\mathrm{Rp} 6.000 .000$ dengan rincian gaji bagian kontruksi sebesar Rp 4.000.000, gaji bagian instrumen sebesar Rp 1.000.000 dan gaji bagian pengecatan sebesar Rp 1.000.000.

\section{Perhitungan Biaya Overhead pabrik}

Penulis menghitung biaya overhead pabrik berdasarkan tarif yang ditentukan dimuka dengan menggunakan dasar pembebanan bahan baku. Dasar pembebanan tersebut diajukan penulis dengan alasan bahwa biaya yang paling dominan jumlahnya adalah biaya bahan baku. Oleh karena itu, untuk dapat menggunakan dasar pembebanan tersebut, informasi yang dibutuhkan adalah pemakaian bahan 
baku dan taksiran pemakaian biaya overhead pabrik. Berikut ini adalah tabel dari biaya pemakaian bahan baku dan taksiran pemakaian biaya overhead pabrik.

Angka ini kemudian dijadikan penulis sebagai taksiran biaya overhead pabrik tahun 2018, maka tarif biaya overhead pabrik ditentukan dimuka adalah sebagai berikut:

\begin{tabular}{|c|c|c|c|c|}
\hline \multirow[t]{4}{*}{ Tarif Biaya Overhead Pabrik } & $=$ & $\frac{\text { Biaya Overhead Pabrik }}{\text { Biaya Bahan Baku }}$ & $\mathrm{x}$ & $100 \%$ \\
\hline & & Rp5.120.435.926,00 & & \\
\hline & & Rp5.726.358.000,00 & $\mathrm{X}$ & $100 \%$ \\
\hline & $=$ & $89,42 \%$ & & \\
\hline
\end{tabular}

Perhitungan diatas menunjukkan bahwa tarif biaya overhead pabrik ditentukan dimuka sebesar $89,42 \%$. Setelah mengetahui prosentase dari tarif biaya overhead pabrik ditentukan dimuka, maka dapat ditentukan pembebanan biaya overhead pabrik untuk produksi pesanan Dump Dropside Light Truck dengan dasar pemakaian bahan baku untuk setiap unit pesanan adalah sebagai berikut.

Tabel 5

Taksiran Biaya Bahan Baku Tahun 2017

\begin{tabular}{llr}
\hline NO & BULAN & TOTAL \\
\hline 1 & Januari & 433.815 .000 \\
2 & Februari & 404.894 .000 \\
3 & Maret & 578.420 .000 \\
4 & April & 390.433 .500 \\
5 & Mei & 563.959 .500 \\
6 & Juni & 404.894 .000 \\
7 & Juli & 563.959 .500 \\
8 & Agustus & 535.038 .500 \\
9 & September & 274.749 .500 \\
10 & Oktober & 607.341 .000 \\
11 & November & 607.341 .000 \\
12 & Desember & 361.512 .500 \\
& TOTAL & 5.726 .358 .000 \\
\hline
\end{tabular}

Sumber : Data CV Berdikari Jaya (2018)

\section{Tabel 6}

Taksiran Biaya Overhead Pabrik Sesungguhnya Tahun 2017

\begin{tabular}{llc}
\hline No & Nama bahan & Jumlah \\
\hline 1 & Fee Marketing & 352.000 .000 \\
2 & Biaya Pengiriman Unit & 69.200 .000 \\
3 & Biaya Surat-Surat Kendaraan & 1.319 .500 .000 \\
4 & Biaya Listrik & 56.977 .426 \\
5 & Gaji Mandor Kontruksi & 60.000 .000 \\
6 & Gaji Mandor Instrumen & 60.000 .000 \\
7 & Gaji Mandor Pengecatan & 60.000 .000 \\
8 & Gaji Kepala Gudang & 48.000 .000 \\
9 & Gaji Adm. Pabrik & 42.000 .000 \\
10 & Gaji Bagian Marketing & 90.000 .000 \\
11 & Biaya Pemeliharaan Mesin & 14.360 .000 \\
12 & Biaya Pemeliharaan Pabrik & 23.542 .500 \\
13 & Biaya Bahan penolong & 2.924 .856 .000 \\
& TOTAL & 5.120 .435 .926 \\
\hline
\end{tabular}

Sumber : Data CV Berdikari Jaya (2018) 
Tabel 7

Perhitungan Harga Pokok Produksi Menurut Penulis

\begin{tabular}{ll}
\hline Biaya Produksi & Total \\
\hline Biaya Bahan Baku & $\mathrm{Rp} 14.460 .500,00$ \\
Biaya Tenaga Kerja Langsung & $\mathrm{Rp} 6.000 .000,00$ \\
Biaya Overhead Pabrik & $12.930 .393,75$ \\
$89,42 \%$ x Rp 14.460.000,00 & \\
Total Biaya Produksi & $\mathrm{Rp} \mathrm{33.390.893,75}$ \\
\hline
\end{tabular}

Sumber: Data Diolah, 2018

Tabel 8

Perbandingan Harga Pokok Produksi Menurut Perusahaan dan Menurut Penulis

\begin{tabular}{lllll}
\hline Jenis Biaya & Menurut Perusahaan & Menurut Penulis & Selisih \\
\hline Biaya Bahan Baku & Rp 21.846.500,00 & Rp 14.460.500,00 & Rp 7.386.000,00 \\
$\begin{array}{l}\text { Biaya Tenaga Kerja } \\
\text { Langsung }\end{array}$ & Rp 6.000.000,00 & Rp 6.000.000,00 & \multicolumn{1}{l}{-} \\
$\begin{array}{l}\text { Biaya Overhead } \\
\text { pabrik }\end{array}$ & $R p ~ 6.700 .000,00$ & Rp 12.930.393,75 & -Rp 6.230.393,75 \\
$\begin{array}{l}\text { Harga Pokok } \\
\text { Produksi }\end{array}$ & Rp 34.546.500,00 & Rp 33.390.893,75 & Rp 1.155.606,25 \\
\hline
\end{tabular}

Sumber: Data Diolah, 2018

\section{Perbandingan Perhitungan Harga Pokok Produksi Menurut Perusahaan dengan Penulis}

Berdasarkan analisis data dan pembahasan yang telah dijelaskan, berikut ini adalah perbandingan perhitungan harga pokok produksi yang dilakukan oleh perusahaan dengan perhitungan pokok produksi yang dilakukan oleh penulis:

a. Analisis Perbandingan Biaya Bahan Baku

Dari hasil analisa terdapat perbedaan perhitungan dikarenakan perusahaan memasukkan biaya bahan penolong yang seharusnya dimasukkan dalam Biaya Overhead Pabrik pada pembebanan biaya bahan baku sehingga terjadi selisih yang signifikan antara perhitungan menurut perusahaan dengan penulis yaitu sebesar Rp 7.386.000,00.

b. Analisis Perbandingan Biaya Tenaga Kerja Langsung

Dalam tabel 4.8 biaya tenaga kerja langsung menurut perusahaan dengan biaya tenaga kerja langsung menurut penulis adalah sama yaitu $\mathrm{Rp}$ 6.000.000,00. Hal ini dikarenakan pembebanan biaya tenaga kerja langsung yang dibuat perusahaan telah sesuai dengan metode job order costing yaitu biaya ditentukan diawal serta dipisahkan antar pesanan.

c. Analisis Perbandingan Biaya Overhead Pabrik

Dalam tabel 4.8 terlihat bahwa ada selisih biaya overhead pabrik antara perhitungan menurut perusahaan dengan perhitungan menurut penulis sebesar $\mathrm{Rp} 6.230 .393,75$. Perbedaan ini dikarenakan perusahaan mencatat biaya overheadpabrik sesungguhnya yang terjadi. Sedangkan penulis menggunakan pembenanan biaya overhead pabrik dimuka yaitu dengan menggunakan dasar pembebanan biaya bahan baku. Hal ini dikarenakan jumlah biaya bahan baku lebih dominan daripada biaya yang lainnya. 
d. Analisis Perbandingan Harga Pokok Produksi

Perhitungan harga pokok produksi perusahaan lebih tinggi Rp 1.155.606,25 dari perhitungan menurut penulis. Hal ini akan berdampak pada penentuan harga jual perusahaan yang dinilai akan lebih tinggi serta perhitungan laba yang tidak tepat. Selain itu perhitungan harga pokok produksi perusahaan yang lebih tinggi akan berdampak pada keputusan perusahaan dalam menilai suatu pesanan diterima atau ditolak.

\section{Tabel 9}

Perbandingan Biaya Bahan Baku Menurut Perusahaan dan Menurut Penulis

Perhitungan Biaya Bahan Baku Perhitungan Biaya Bahan Baku

$$
\text { Menurut Perusahaan }
$$

$$
\text { Menurut Penulis }
$$

\begin{tabular}{|c|c|c|c|c|}
\hline Nama Bahan & Total & Nama Bahan & Total & \\
\hline Plat $1,4 \mathrm{X} 4 \mathrm{X} 8$ & $560.000,00$ & Plat $1,4 \mathrm{X} 4{ }^{\prime} \mathrm{X} 8$ & $560.000,00$ & - \\
\hline Plat $2,8 \mathrm{X} 4^{\prime} \mathrm{X} 8^{\prime}$ & $3.360 .000,00$ & Plat $2,8 X 4^{\prime} \mathrm{X} 8{ }^{\prime}$ & $3.360 .000,00$ & - \\
\hline Plat $3,5 \mathrm{X} 4^{\prime} \mathrm{X} 8$ & $712.000,00$ & Plat $3,5 \mathrm{X} 4{ }^{\prime} \mathrm{X} 8$ & $712.000,00$ & - \\
\hline Plat $3,8 \mathrm{X} 4 \mathrm{X} 8$ & $2.589 .000,00$ & Plat $3,8 \mathrm{X} 4{ }^{\prime} \mathrm{X} 8$ & $2.589 .000,00$ & - \\
\hline $\begin{array}{l}\text { Plat Strip } 6 \times 3 / 4 \\
\times 6\end{array}$ & $345.000,00$ & $\begin{array}{l}\text { Plat Strip } 6 \times \\
3 / 4 \times 6\end{array}$ & $345.000,00$ & - \\
\hline Plat Afalan $6 \mathrm{~mm}$ & $450.000,00$ & $\begin{array}{l}\text { Plat Afalan } \\
6 \mathrm{~mm}\end{array}$ & $450.000,00$ & - \\
\hline $\begin{array}{l}\text { UNP/Kanal } \\
100 X 6 \mathrm{mtr}\end{array}$ & $2.320 .000,00$ & $\begin{array}{l}\text { UNP/Kanal } \\
100 X 6 \mathrm{mtr}\end{array}$ & $2.320 .000,00$ & - \\
\hline $\begin{array}{l}\text { UNP/Kanal } \\
120 X 6 \mathrm{mtr}\end{array}$ & $1.732 .000,00$ & $\begin{array}{l}\text { UNP/Kanal } \\
120 X 6 \mathrm{mtr}\end{array}$ & $1.732 .000,00$ & - \\
\hline $\begin{array}{l}\text { UNP/Kanal } 65 X 6 \\
\mathrm{mtr}\end{array}$ & $360.000,00$ & $\begin{array}{l}\text { UNP/Kanal } \\
65 X 6 \mathrm{mtr}\end{array}$ & $360.000,00$ & - \\
\hline $\begin{array}{l}\text { UNP/Kanal 80X6 } \\
\mathrm{mtr}\end{array}$ & $1.785 .000,00$ & $\begin{array}{l}\text { UNP/Kanal } \\
80 X 6 \mathrm{mtr}\end{array}$ & $1.785 .000,00$ & - \\
\hline $\begin{array}{l}\text { UNP/Kanal } \\
150 X 6 \mathrm{mtr}\end{array}$ & $247.500,00$ & $\begin{array}{l}\text { UNP/Kanal } \\
150 X 6 \mathrm{mtr}\end{array}$ & $247.500,00$ & - \\
\hline Hydraulic & $3.700 .000,00$ & & & $3.700 .000,00$ \\
\hline Kawat Las & $576.000,00$ & & & $576.000,00$ \\
\hline Pompa & $1.350 .000,00$ & & & $1.350 .000,00$ \\
\hline Sparepart & $1.230 .000,00$ & & & $1.230 .000,00$ \\
\hline $\begin{array}{l}\text { Perlengkapan } \\
\text { Baut }\end{array}$ & $320.000,00$ & & & $320.000,00$ \\
\hline Accecories & $210.000,00$ & & & $210.000,00$ \\
\hline TOTAL & $21.846 .500,00$ & TOTAL & $14.460 .500,00$ & $7.386 .000,00$ \\
\hline
\end{tabular}

SELISIH

Sumber: Data Diolah, 2018 


\begin{tabular}{|c|c|c|c|c|}
\hline \multicolumn{5}{|c|}{$\begin{array}{c}\text { Tabel } 10 \\
\text { Tabel Perbandingan Biaya Overhead Pabrik Menurut Perusahaan } \\
\text { dan Menurut Penulis }\end{array}$} \\
\hline \multicolumn{2}{|c|}{$\begin{array}{l}\text { Perhitungan Biaya Overhead } \\
\text { Pabrik Menurut Perusahaan }\end{array}$} & \multicolumn{2}{|c|}{$\begin{array}{l}\text { Perhitungan Biaya Overhead } \\
\text { Pabrik Menurut Penulis }\end{array}$} & \multirow[t]{2}{*}{ SELISIH } \\
\hline Keterangan & Total & Keterangan & Total & \\
\hline Fee Marketing & 1.000 .000 & & & \\
\hline Biaya Pengiriman & 200.000 & $\begin{array}{l}\text { Pembebanan } \\
\text { Biaya Overhead }\end{array}$ & & \\
\hline $\begin{array}{l}\text { Unit } \\
\text { Biaya Surat-Surat } \\
\text { Kendaraan }\end{array}$ & 3.500 .000 & $\begin{array}{l}\text { Pabrik Dimuka: } \\
89,42 \% \text { x }\end{array}$ & $12.930 .393,75$ & \\
\hline Biaya Lain-Lain & 2.000 .000 & $14.460 .000,00$ & & \\
\hline TOTAL & $6.700 .000,00$ & TOTAL & $12.930 .393,75$ & $6.230 .393,75$ \\
\hline
\end{tabular}

Sumber: Data Diolah, 2018

\section{SIMPULAN}

Berdasarkan hasil penelitian dan pembahasan mengenai analisis penerapan Metode Job Order Costing CV. Berdikari Jaya, diperoleh simpulan sebagai berikut. Pengumpulan biaya tenaga kerja langsung yang dilakukan perusahaan CV Berdikari jaya sudah tepat. Namun perhitungan biaya bahan baku danpembebanan biaya overhead pabrik yang dilakukan perusahaan CV Berdikari Jaya kurang tepat. Hal ini terjadi karena tidak ada pemisahan antara biaya bahan baku dengan biaya bahan penolong. Selain itu pembebanan biaya overhead pabrik yang tidak tepat karena perusahaan membebankan biaya lain-lain pada setiap pesanan sebanyak Rp 2.000.000 sebagai taksiran atas biaya overhead pabrik nonkas. Perusahan belum membuat kartu harga pokok pesanan yang berfungsi untuk mencatat secara rinci pengumpulan biaya produksi tiap pesanan produk tertentu sesuai kebutuhan perusahaan. Penentuan harga pokok produksi yang dilakukan perusahaan dan penulis ada perbedaan dalam pembebanan biaya overhead pabrik. Biaya overheadpabrik menurut perusahaan berdasarkan pada biaya overhead pabrik yang sesungguhnya pada setiap pesanan dengan menambahkan biaya lain-lain. Sedangkan penulis menghitung biaya overhead pabrik berdasarkan tarif yang ditentukan dimuka dengan menggunakan dasar pembebanan bahan baku.

\section{DAFTAR PUSTAKA}

Bustomi, Bastian dan Nurlela 2013, Akuntansi Biaya, Mitra Wacana Media, Bogor

Dunia, Firdaus Ahmad dan Abdul Wasilah 2012, Akuntansi Biaya Edisi 3, Salemba Empat, Jakarta

Fardhani, Nizar, Jenny Morasa dan Anneke Wangkar 2016, Evaluasi Penerapan Job Order Costing Method dalam Penentuan Harga Pokok Produksi Pada CV Visual Komunika Mandiri, Jurnal Akuntansi Biaya, Vol. 16 $\begin{array}{lllll}\text { No. 04, Retrieved } 7 & \text { Desember } & \text { 2017, }\end{array}$ https://ejournal.unsrat.ac.id/index.php/jbie/article/- view/13694/13276 
Garrison, Noreen \& Brewer 2013. Akuntansi Manajerial Buku Dua Edisi keempatbelas, Diterjemahkan oleh Kartika Dewi, Salemba Empat, Jakarta

Hansen dan Mowen 2001, Akuntansi Manajemen Jilid 2, Salemba Empat, Jakarta

Kusumawardani, Rully 2013, Perhitungan Harga Pokok Produksi Menggunakan Metode Job Order Costing pada CV Tristar, Jurnal Akuntansi Biaya, Retrieved 7 Desember 2017, From https://www.scribd.com/document/345839544/ipi189033-pdf

Lestari, Wiwik dan Dhyka Bagus Permana 2017, Akuntansi Biaya dalam Perspektif Manajerial, Rajawali Pers, Jakarta

Mulfi, Ade Putri 2013, Analisis Harga Pokok Produksi Dengan Metode Job Order Costing, Jurnal Skripsi, Retrieved 7 Desember 2017, From repository.ipb.ac.id/bitstream/123456789/63899/1/H13adm.pdf

Mulyadi 2007, Akuntansi Biaya Edisi 3, UPP STIM YKPN Universitas Gadjah mada, Jogjakarta

Mulyadi 2010, Akuntansi Biaya Edisi 5, UPP STIM YKPN Universitas Gadjah Mada, Jogjakarta

Mulyadi 2012, Akuntansi Biaya Edisi 5, UPP STIM YKPN Universitas Gadjah Mada, Jogjakarta

Mulyadi 2014, Akuntansi Biaya Edisi 5, UPP STIM YKPN Universitas Gadjah Mada, Jogjakarta

Mulyadi 2015, Akuntansi Biaya Edisi 5, UPP STIM YKPN Universitas Gadjah Mada, Jogjakarta

Satori, Djam'an dan Aan Komariah 2013, Metodologi Penelitian Kualitatif, Alfabeta, Bandung

Sudaryanto, Eko Rohmat 2009, Evaluasi Penentuan Harga Pokok Produksi Berdasarkan Metode Job Order Costing Pada Perusahaan Batik Fendy Klaten, Tugas Akhir, Retrieved 7 Desember 2017. From https://eprints.uns.ac.id/-4829/1/161912608201011311.pdf

Sugiyono 2013, Metode Penelitian Kuantitatif Kualitatif dan $R \quad \& \quad D$, Alfabeta, Bandung

Supriyono 2011. Akuntansi Biaya, BPFE Yogyakarta, Yogyakarta. 